\title{
The Economic Structure of Fiduciary Law
}

\section{Citation}

Robert H. Sitkoff, The Economic Structure of Fiduciary Law, 91 B.U. L. Rev. 1039 (2011).

\section{Published Version}

http://www.bu.edu/law/central/jd/organizations/journals/bulr/documents/SITKOFF.pdf

\section{Permanent link}

http://nrs.harvard.edu/urn-3:HUL.InstRepos:14976369

\section{Terms of Use}

This article was downloaded from Harvard University's DASH repository, and is made available under the terms and conditions applicable to Other Posted Material, as set forth at http:// nrs.harvard.edu/urn-3:HUL.InstRepos:dash.current.terms-of-use\#LAA

\section{Share Your Story}

The Harvard community has made this article openly available.

Please share how this access benefits you. Submit a story.

\section{Accessibility}




\title{
THE ECONOMIC STRUCTURE OF FIDUCIARY LAW
}

\author{
ROBERT H. SITKOFF*
}

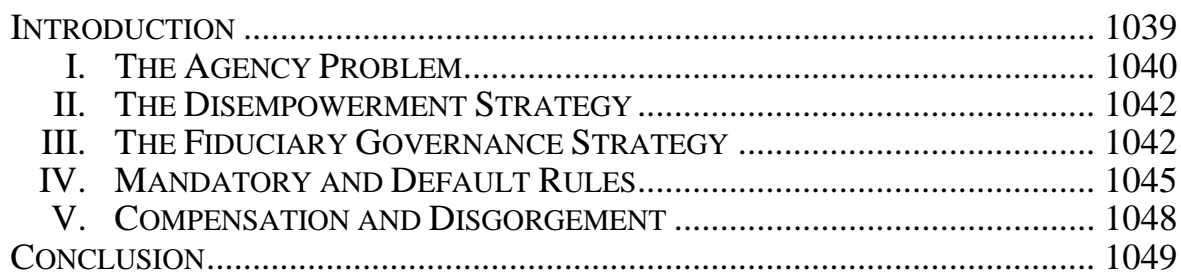

\section{INTRODUCTION}

This Symposium on Fiduciary Law in the Twenty-First Century provides an opportune moment to revisit the economic theory of fiduciary law. Nearly two decades have passed since the publication of the seminal economic analyses of fiduciary law by Cooter and Freedman (1991), and by Easterbrook and Fischel (1993), which together have come to underpin the prevailing economic, contractarian model of fiduciary law. ${ }^{1}$ The economic theory of agency that

* John L. Gray Professor of Law, Harvard University (email: rsitkoff@law.harvard.edu). This Essay derives from the Author's remarks at the Symposium on The Role of Fiduciary Law and Trust in the Twenty-First Century: A Conference Inspired by the Work of Tamar Frankel, held at Boston University School of Law on October 29, 2010; and from the Author's remarks in prior events sponsored by Federated Investors, Inc., in New York on February 2, 2010, and in Boston on September 15, 2009. The Author thanks Jonathan Klick, John Langbein, and Max Schanzenbach for helpful comments on an earlier draft, and Teresa Gallego-O'Rourke and R. Craig Kitchen for superb research assistance.

${ }^{1}$ See Robert Cooter \& Bradley J. Freedman, The Fiduciary Relationship: Its Economic Character and Legal Consequences, 66 N.Y.U. L. REV. 1045 (1991); Frank H. Easterbrook \& Daniel R. Fischel, Contract and Fiduciary Duty, 36 J.L. \& ECON. 425 (1993). There is, of course, a thick literature on the fiduciary obligation. See, e.g., Matthew Conaglen, Fiduciary loyalty: Protecting the Due Performance of Non-Fiduciary Duties (2010); LeONARD I. Rotman, Fiduciary Law (2005); Gregory S. Alexander, A Cognitive Theory of Fiduciary Relationships, 85 CORNELL L. REV. 767 (2000); Rob Atkinson, Obedience as the Foundation of Fiduciary Duty, 34 J. CORP. L. 43 (2008); Henry N. Butler \& Larry E. Ribstein, Opting Out of Fiduciary Duties: A Response to the AntiContractarians, 65 Wash. L. ReV. 1 (1990); Robert C. Clark, Agency Costs versus Fiduciary Duties, in Principals AND Agents: The StRUCTURE of Business 55 (John W. Pratt \& Richard J. Zeckhauser eds., 1985); Deborah A. DeMott, Beyond Metaphor: An Analysis of Fiduciary Obligation, 1988 DUKE L.J. 879; Claire Moore Dickerson, From Behind the Looking Glass: Good Faith, Fiduciary Duty and Permitted Harm, 22 FLA. ST. U. 
motivates those papers has come to permeate the literature on law and legal institutions generally. ${ }^{2}$ The law-and-economics movement has matured further, developing new tools and refining its understanding of previously applied concepts. The purpose of this Essay is to restate the economic theory of fiduciary law in an updated and accessible synthesis.

\section{THE AGENCY PROBLEM}

The law tends to impose a fiduciary obligation in circumstances that present what economists call a principal-agent or agency problem. Agency problems are not limited to relationships that are governed by the common law of agency. On the contrary, an agency problem arises whenever one person, the principal, engages another person, the agent, to undertake imperfectly observable discretionary actions that affect the wealth of the principal. ${ }^{3}$ The concern is that in exercising this unobservable discretionary authority, the agent will favor the agent's interests when the agent's interests diverge from those of the principal. Agency problems are common because no one has the time and skills necessary to do everything for himself.

Removing or limiting the agent's discretion is not a satisfactory answer to the agency problem. Often the principal cannot spell out in advance what precisely the agent should do in all possible future circumstances. This problem of incomplete contracting arises from transaction costs - the impossibility of anticipating all future contingencies and the infeasibility of reducing to writing instructions for every contingency that can be anticipated. In many circumstances the very purpose of retaining an agent with expertise is

L. ReV. 955 (1995); Scott FitzGibbon, Fiduciary Relationships Are Not Contracts, 82 MARQ. L. Rev. 303 (1999); Robert Flannigan, The Economics of Fiduciary Accountability, 32 Del. J. CoRp. L. 393 (2007); Tamar Frankel, Fiduciary Duties as Default Rules, 74 OR. L. REv. 1209 (1995); Arthur B. Laby, The Fiduciary Obligation as the Adoption of Ends, 56 Buff. L. Rev. 99 (2008); Melanie B. Leslie, Trusting Trustees: Fiduciary Duties and the Limits of Default Rules, 94 Geo. L.J. 67 (2005); R.C. Nolan, Controlling Fiduciary Power, 68 CAMBRIDGE L.J. 293 (2009); L.S. Sealy, Fiduciary Relationships, 1962 CAMBRIDGE L.J. 69 (1962); J.C. Shepherd, Towards a Unified Concept of Fiduciary Relationships, 97 L.Q. REV. 51 (1981); D. Gordon Smith, The Critical Resource Theory of Fiduciary Duty, 55 VAND. L. REV. 1399 (2002); Ernest J. Weinrib, The Fiduciary Obligation, 25 U. TORONTO L.J. 1 (1975). Tamar Frankel's new book represents a capstone synthesis of her important contributions to this literature. See TAMAR Frankel, FiduCIARY LAW (2011).

${ }^{2}$ For example, in FrANKEL, supra note 1, at 25-29, 104-107, 171-74, we find various functional treatments of fiduciary law that are in sympathy with the agency theory sketched below. I have elsewhere urged an agency theory of trust law. See Robert H. Sitkoff, An Agency Theory of Trust Law, 89 CORNELl L. REV. 621 (2004); see also JESSE DuKEMINIER, Robert H. Sitkoff \& James Lindgren, Wills, Trusts, And Estates 670-72 (8th ed. 2009); Jonathan Klick \& Robert H. Sitkoff, Agency Costs, Charitable Trusts, and Corporate Control: Evidence from Hershey's Kiss-Off, 108 CoLUM. L. REV. 749, 779-83 (2008).

3 See Michael C. Jensen \& William H. Meckling, Theory of the Firm: Managerial Behavior, Agency Costs and Ownership Structure, 3 J. FIn. Econ. 305, 308 (1976). 
undermined if the agent is not given room to apply that expertise on behalf of the principal to changing conditions.

Active monitoring is not a satisfactory answer to the agency problem. Even if the principal has spelled out what the agent should do in a particular contingency, it is often infeasible for the principal to monitor the agent's compliance with those instructions. Agents are often retained because the principal lacks the specialized skills necessary to undertake the activity on his own. In such a case, the skill deficit that prompted the principal to engage the agent will limit the principal's ability to monitor the agent.

Judging the agent on the basis of the agent's results is likewise an imperfect mechanism for resolving the agency problem because circumstances outside of the agent's control may affect the outcome. Suppose a real estate agent cannot locate a suitable buyer for a home at the homeowner's desired price. The homeowner can seldom ascertain whether the agent's failure reflects the agent's inadequate effort versus the homeowner's overpricing or a slumping market. The homeowner's inability to assess the cause of the agent's failure is a kind of post-contractual information asymmetry known as hidden action or moral hazard. ${ }^{4}$

Another often-discussed means for ameliorating the agency problem is an incentive-based compensation arrangement. A real estate agent, for example, is typically compensated by a percentage of the sale price to give the agent a financial incentive to maximize that price. But no compensation agreement short of selling the house to the agent will completely remove the possibility of divergence of interest and with it the temptation for the agent to favor the agent's own interests. Suppose, for example, a real estate agent working on a $5 \%$ commission. Such an agent will have no incentive to undertake $\$ 100$ of additional effort to increase the sale price by $\$ 1,000$, because the payoff to the agent of doing so is only $\$ 50$ (5\% of $\$ 1,000) .{ }^{5}$ By contrast, if the agent owned the home he would undertake the additional $\$ 100$ in effort for the $\$ 1,000$ increase in the sale price. But solving the incentive problem by selling the house to the agent - in effect, removing the agency - is often impractical. The typical real estate agent could not bear the risk of buying his clients' homes for resale (a risk-sharing problem ${ }^{6}$ ), and his clients would still be dependent on his faithfulness in pricing the home (a hidden information or adverse selection problem ${ }^{7}$ ).

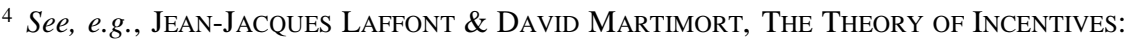
The PrincIPAL-AgENT MOdel 3 (2002).

5 This example derives from Frank H. Easterbrook \& Daniel R. Fischel, The ECONOMIC STRUCTURE OF CORPORATE LAW 91 (1991).

${ }^{6}$ Agency relationships, in other words, present both incentive and risk-sharing problems. See, e.g., Cooter \& Freedman, supra note 1, at 1068; Kathleen M. Eisenhardt, Agency Theory: An Assessment and Review, 14 ACAD. MGMt. Rev. 57, 58 (1989).

${ }^{7}$ See, e.g., LAFFONT \& MARTIMORT, supra note 4, at 3.
} 
The losses and other inefficiencies resulting from the misalignment of the principal's and the agent's interests are called agency costs. ${ }^{8}$ The goal in regulating an agency relationship is to minimize agency costs. The question is how to induce the agent to act in the best interests of the principal in circumstances in which the agent must exercise discretion in ways that the principal cannot effectively observe or verify.

\section{THE DisEMPOWERMENT STRATEGY}

Over the years the law evolved two basic strategies for addressing agency problems. ${ }^{9}$ The first, which predictably has failed, was to minimize the agent's discretionary powers. Thus in trust law the old rule was that the trustee could not engage in market transactions over the trust property. In agency law the old rule was that the agent's authority terminated on the incapacity of the principal. And in corporate law the old ultra vires doctrine disabled the corporation from undertaking any activity beyond the scope of the company's limited purpose as stated in the company's charter.

The problem with disempowerment is that in protecting the principal from mis- or malfeasance by the agent, the law also disabled the agent from undertaking acts useful for the principal. Thus, because trusts are increasingly funded with liquid financial assets requiring nimble management in the face of swift changes in the conditions of financial markets, modern law gives the trustee broad powers to undertake any type of transaction, subject to the trustee's fiduciary obligation. In agency law, all states have enacted statutes that validate durable powers of attorney authorizing an agent to act on behalf of an incompetent principal, subject to the agent's fiduciary obligation. In corporate law, the ultra vires doctrine has been rendered toothless, and today the corporation may undertake any action in pursuit of profit, subject to the managers' fiduciary obligation.

What has happened, in other words, is that modern law has come to substitute fiduciary obligation for disempowerment as the preferred regulatory response to the agency problem. ${ }^{10}$

\section{THE FIDUCIARY GOVERNANCE STRATEGY}

Under the modern law's fiduciary strategy, the agent is given broad discretionary powers to act in the moment, but afterwards the principal is

\footnotetext{
8 See Jensen \& Meckling, supra note 3, at 308.

${ }^{9}$ For a treatment of additional strategies beyond fiduciary law, albeit with a focus on corporate governance, see John Armour, Henry Hansmann \& Reinier Kraakman, Agency Problems and Legal Strategies, in The Anatomy of Corporate Law: A Comparative AND FunCtional APPROACH 35 (Reinier Kraakman et al. eds., 2d ed. 2009).

10 This point has been developed extensively with a focus on trust law by John Langbein. See John H. Langbein, The Contractarian Basis of the Law of Trusts, 105 YALE L.J. 625, 640-43 (1995); John H. Langbein, Rise of the Management Trust, TR. \& EsT., Oct. 2004, at 52.
} 
invited to scrutinize whether the agent's action was indeed in the principal's best interests. Stripped of legalistic formalisms and moralizing rhetoric, ${ }^{11}$ the functional core of the fiduciary obligation is deterrence. ${ }^{12}$ The agent is induced to act in the best interests of the principal by the threat of after-the-fact liability for failure to have done so. The agent is given broad discretionary powers, but the agent must exercise that discretion in the best interests of the principal on pain of damages and disgorgement remedies.

Viewed in this manner, the operation of the fiduciary obligation becomes intuitive. The core fiduciary duties are the duties of loyalty and care. The duty of loyalty proscribes misappropriation and regulates conflicts of interest by requiring the fiduciary to act in the "best" or even "sole" interests of the principal. The duty of loyalty presumptively prohibits self-dealing, subjecting the principal's consent to such actions to procedural and substantive safeguards, chief among them full and fair disclosure by the fiduciary. ${ }^{13}$ The aim is to induce the fiduciary either to refrain from self-dealing or to disclose the material facts of the transaction and how the fiduciary's conflict might compromise the fiduciary's judgment, thereby enabling the principal to make an informed decision whether to consent. ${ }^{14}$ In concert with the availability of a disgorgement remedy for breach, the prophylactic ban on self-dealing thus serves a disclosure or revelatory purpose. ${ }^{15}$

The duty of care prescribes the fiduciary's standard of care by establishing a "reasonableness" or "prudence" standard in which the meaning of reasonableness or prudence is informed by industry norms and practices. This standard of care is objective, measured by reference to a reasonable or prudent person in like circumstances. ${ }^{16}$ If the fiduciary has specialized skills relevant

11 The most famous such rhetoric is that of Judge Cardozo in Meinhard v. Salmon, 164 N.E. 545 (N.Y. 1928):

Many forms of conduct permissible in a workaday world for those acting at arm's length, are forbidden to those bound by fiduciary ties. A trustee is held to something stricter than the morals of the market place. Not honesty alone, but the punctilio of an honor the most sensitive, is then the standard of behavior. As to this there has developed a tradition that is unbending and inveterate. Uncompromising rigidity has been the attitude of courts of equity when petitioned to undermine the rule of undivided loyalty by the 'disintegrating erosion' of particular exceptions. Only thus has the level of conduct for fiduciaries been kept at a level higher than that trodden by the crowd. It will not consciously be lowered by any judgment of this court.

Id. at 546 (citations omitted).

12 See Frank H. Easterbook \& Daniel R. Fischel, Corporate Control Transactions, 91 YALE L.J. 698, 702 (1982).

13 See, e.g., RESTATEMENT (ThiRd) OF Trusts $\$ 78$, cmts. c-d (2007); RESTATEMENT (THIRD) OF AGENCY $§ \S ~ 8.01-8.06$ (2006); PRINCIPLES OF CORPORATE GOVERNANCE: ANALYSIS AND RECOMMENDATIONS $§ 5.01-5.02$ (1994).

14 See, e.g., RESTATEMENT (THIRD) OF AGENCY $\$ 8.06$, cmt. b (2006).

15 See infra text accompanying note 37.

16 See, e.g., Restatement (ThIRD) OF TRUsts $\$ 77$ (2007); REsTATEMENT (THIRD) OF Agency $\$ 8.08$ (2006); Principles of Corporate Governance: ANAlysis AND 
to the principal's retention of the fiduciary, then the applicable standard of care is that of a reasonable or prudent person in possession of those skills. ${ }^{17}$

Because agency problems arise from incomplete contracting, the core duties of loyalty and care are phrased in open-ended, expansive terms. The duties of loyalty and care are thus standards that allow the court to decide whether, in view of all the facts and circumstances, the fiduciary acted in accord with what the parties would have agreed if they had been able to anticipate those facts and circumstances. In effect, the loyalty and care standards empower the court to complete the parties' contract as regards the facts and circumstances as they in fact unfolded. The duties of loyalty and care therefore minimize transaction costs. Instead of trying in advance to reduce to writing provisions for every future contingency, the parties need only address expressly those contingencies that are important and likely enough to warrant the transaction costs of express provision. For all other contingencies, the fiduciary obligation fills the gap.

As standards that allow for consideration of all the relevant facts and circumstances, the duties of loyalty and care also minimize error costs. But as is typical of standards (as compared to rules), this reduction in error costs comes at the price of increased uncertainty and increased decision costs. ${ }^{18}$ The highly contextual nature of a standard makes prediction more difficult and requires a more intensive judicial role. Two related fiduciary law developments, however, mitigate these costs.

First, the normal accretive process of the common law has produced a rich body of interpretive authority on fiduciary matters, not only across decades of case law, but also across generations of treatises, restatements, and statutory codifications. This mass of authority improves predictability by providing instructive guidance on how the duties of loyalty and care will be applied in various circumstances. This mass of authority also addresses the extent to which the parties may override the fiduciary obligation by explicit agreement and the remedies available to the principal for the fiduciary's breach of duty.

Second, accumulated experience with recurring, common sets of facts and circumstances has led to the development of subsidiary or implementing rules regarding the application of the duties of loyalty or care to those circumstances. The corporate opportunities doctrine and the trust law nofurther-inquiry rule (and its proliferating exceptions) are examples of such rules. ${ }^{19}$ So too are the specific rules in agency and corporate law regarding competition with the principal or the corporation. ${ }^{20}$ Other common examples

\footnotetext{
RECOMMENDATIONS § 4.01(a) (1994).

17 See, e.g., UNIFORM PRUdENT INVESTOR ACT $§ 2$ (f) (1994); RESTATEMENT (THIRD) OF TRusts § 77(3) (2007); RESTATEMENT (THIRD) OF AGENCY $\$ 8.08$ (2006).

18 See, e.g., Louis Kaplow, Rules Versus Standards: An Economic Analysis, 42 DuKE L.J. 557 (1992).

19 See Restatement (Third) of Trusts § 78, cmts. c-d (2007); Principles of Corporate GOVERnANCE: ANALYSIS AND RECOMMENDATIONS § 5.05 (1994).

${ }^{20}$ See Restatement (Third) of Agency $§ 8.04$ (2006); Principles of Corporate
} 
are specific rules on reasonable compensation, disclosure, accurate recordkeeping, and commingling funds.

The subsidiary or implementing rules simplify application of the fiduciary obligation to cases that fall within their terms, reducing decision costs. ${ }^{21}$ One need not show that the duty of care requires accurate recordkeeping, for example, if one can invoke a subsidiary rule that imposes such a duty. Moreover, the subsidiary rules offer the normal benefit of simple rules, reduced decision costs, without increasing error costs by providing a roadmap for strategic avoidance behavior. If the fiduciary acts in a manner that is inimical to the principal's interests but that does not fall within one or another subsidiary rule, the principal may invoke the broad, open-ended duties of loyalty and care. Operating in tandem, the broad duties of loyalty and care plus the specific subsidiary rules provide the decision costs advantage of rules and the error costs advantage of standards. ${ }^{22}$

Because the fiduciary obligation operates as an after-the-fact compliance review of the fiduciary's conduct, and because the agency problem varies across fiduciary contexts, the precise contours of the fiduciary obligation vary across the fiduciary fields. For example, the fiduciary obligation in trust law is generally stricter than the fiduciary obligation in corporate law. But those differences reflect the different contexts. The agency problem in a family trust in which the beneficiaries have no exit option and that is managed by a corporate fiduciary that cannot easily be replaced differs significantly from the agency problem in a large, publicly-traded corporation from which a shareholder can separate easily by selling his shares in a thick securities market (the "Wall Street rule"). ${ }^{23}$

The flexibility of the fiduciary obligation explains the success of the fiduciary governance strategy. Over the years the courts and more recently the legislatures have adapted the duties of loyalty and care and have created subsidiary, implementing duties to fit the particulars of the agency problem at issue.

\section{Mandatory AND Default Rules}

Fiduciary duties yield to the contrary agreement of the parties. This principle follows naturally from the nature of fiduciary governance as a system of deterrence meant to minimize agency costs by allowing the court to complete the contract after the fact. The requirement of fiduciary law that the

GOVERNANCE: ANALYSIS AND RECOMMENDATIONS § 5.06 (1994).

${ }^{21}$ See Sitkoff, supra note 2, at 682-83.

${ }^{22}$ I have elsewhere characterized this mode of legal governance as a "standard tempered by presumptions," in comparison to a "rule tempered by exceptions." DukEMINIER, SITKOFF \& LINDGREN, supra note 2, at 386-87.

${ }^{23}$ See Robert H. Sitkoff, Trust Law, Corporate Law, and Capital Market Efficiency, 28 J. CORP. LAw 565 (2003); see also Stephen M. Bainbridge, The Case for Limited Shareholder Voting Rights, 53 UCLA L. REV. 601, 619 (2006). 
fiduciary act in the principal's best interests, which is informed by what the parties would have agreed if they had considered a given contingency, does not pertain with respect to a particular contingency if the parties entered into an express agreement on what the fiduciary should do in the event of that contingency. So the various fiduciary duties are for the most part default rules that apply unless the parties have agreed otherwise.

Even the fiduciary duty of loyalty is subject to modification by agreement of the parties. ${ }^{24}$ If the principal gives informed consent to certain self-dealing by the fiduciary, the rationale for the duty of loyalty's prophylactic rule against self-dealing falls away. In such circumstances, the fiduciary may engage in the specified self-dealing, provided that the fiduciary acts in good faith and that the transaction is objectively fair and in the best interests of the principal. ${ }^{25}$

To be sure, there is a mandatory core to the fiduciary obligation that cannot be overridden by agreement. For example, the principal cannot authorize the fiduciary to act in bad faith. ${ }^{26}$ Even if the principal authorizes self-dealing, fiduciary law provides substantive safeguards, requiring the fiduciary to act in good faith and deal fairly with and for the principal; and procedural safeguards, requiring the fiduciary to apprise the principal of the material facts, which means the facts that would reasonably affect the principal's judgment, in securing the principal's informed consent. ${ }^{27}$

The existence of such mandatory rules vexed the prior generation of economic analysis of fiduciary law. ${ }^{28}$ Committed contractarians have had difficulty explaining why the parties to a fiduciary relationship do not have complete freedom of contract to alter the terms of that relationship. The answer is that the mandatory rules of fiduciary law serve an internal protective and cautionary function that protects the principal, and an external categorization function that protects third parties who deal with the fiduciary.

\footnotetext{
${ }^{24}$ See, e.g., Uniform PowER OF ATtORNEy ACt § 114(b) (2006); RESTATEMENT (THIRD) OF TRUSTS § 78, cmt. c(2) (2007); RESTATEMENT (THIRD) OF AGENCY § 8.06 (2006).

25 See, e.g., Restatement (ThIRD) OF TRusts $\S 78$, cmts. c-d (2007); RESTATEMENT (THIRD) OF AGENCY $§ 8.06$ (2006); PRINCIPLES OF CORPORATE GOVERNANCE: ANALYSIS AND RECOMMENDATIONS $§ 5.02$ (1994).

26 See, e.g., Uniform Power of AtTORNEy Act § 114(a) (2006); UnIFORM TRUST CODE $\S 105$ (b)(2) (2000); RESTATEMENT (ThIRD) OF TRUSTS $\S 78$, cmt. c(2) (2007); RESTATEMENT (THIRD) OF AGENCY § 8.06(1)(a), (2)(a) (2006).

27 See, e.g., RESTATEMENT (THIRD) OF TRUSts $\S 78$, cmt. c(2) (2007); RESTATEMENT (THIRD) OF AGENCY $\S 8.06$ (2006).

${ }^{28}$ For example, Easterbrook and Fischel erroneously asserted that in trust law "[a]ll rules are freely variable by contract in advance." Easterbrook \& Fischel, supra note 1, at 432. Prevailing trust law is to the contrary. See Restatement (ThiRd) of Trusts $\S 78$, cmt. c(2) (2007) (" $[\mathrm{N}] \mathrm{o}$ matter how broad the provisions of a trust may be in conferring power to engage in self-dealing or other transactions involving a conflict of fiduciary and personal interests, a trustee violates the duty of loyalty to the beneficiaries by acting in bad faith or unfairly."); see also John H. Langbein, Mandatory Rules in the Law of Trusts, 98 Nw. U.L. REV. 1105 (2004).
} 
With respect to the internal protective and cautionary function, the mandatory core insulates fiduciary obligations that the law assumes would not be bargained away by a fully informed, sophisticated principal. True, in an individual case a particular principal might be fully informed and have good reason to want to bargain away something from the mandatory core. But such circumstances are infrequent enough that a prophylactic (if paternalistic) mandatory rule may be justified nonetheless, at least in the traditional fiduciary fields such as trust and agency, in which the principal is commonly not sophisticated and fully informed.

With respect to the external categorization function, the mandatory core addresses the need for clean lines of demarcation across types of property arrangements to minimize third-party information costs. This standardization function has been emphasized in the contemporary learning in property theory. ${ }^{29}$ On this view, the mandatory core of fiduciary law polices the line that differentiates a fiduciary relationship on the one hand from a fee simple or other such arrangement on the other. A person may give property to another person and authorize the other person to act whimsically with respect to the property. But this mode of transfer is an absolute gift, and this mode of holding property is fee simple. ${ }^{30}$

The categorization, third-party information costs explanation for the mandatory core is strongest as regards fiduciary relationships for which there is no public notice filing such as agency and common law trusts. ${ }^{31}$ The explanation is weaker as regards filing entities such as corporations and limited liability companies, because the public filing that brings the entity into existence also provides notice to third parties. For this reason, and because the parties in such contexts are more likely to be fully informed and sophisticated,

29 See Henry Hansmann \& Reinier Kraakman, Property, Contract, and Verification: The Numerus Clausus Problem and the Divisibility of Rights, 31 J. LEG. STUD. S373 (2002); Thomas W. Merrill \& Henry E. Smith, Optimal Standardization in the Law of Property: The Numerus Clausus Principle, 110 Yale L.J. 1 (2000); Thomas W. Merrill \& Henry E. Smith, The Property/Contract Interface, 101 Colum. L. REv. 773 (2001); see also Sitkoff, supra note 2 , at 643 .

30 As the Delaware Supreme Court put the point: "A trust in which there is no legally binding obligation is a trust in name only and more in the nature of an absolute estate or fee simple grant of property.” McNeil v. McNeil, 798 A.2d 503, 509 (Del. 2002).

31 See Restatement (ThiRd) of Trusts $\S 78$, cmt. c(2) (2007) (explaining that "to some extent the duty of loyalty involves (as do other duties) more than default law - that is, that there are limits to the settlor's freedom, thereby protecting the fundamental fiduciary character of trust relationships recognized by the law"); RESTATEMENT (THIRD) OF AGENCY $\S 8.06$, cmt. b (2006) ("Common-law agency does not accord effect to all manifestations of assent by a principal that purports to eliminate or otherwise affect the fiduciary duties owed by an agent. This is so for two distinct reasons: (1) the law, and not the parties, determines whether a particular relationship is one of agency . . . ; and (2) the law imposes restrictions on the efficacy of a principal's manifestations of assent in the interest of safeguarding the principal's intention in creating a relationship of common-law agency."). 
the mandatory core for filing fiduciary entities is both less robust and more contentious than in agency and trust law. ${ }^{32}$ Consistent with this analysis, we find in the recent uniform acts in the fiduciary fields a consolidated scheduling of mandatory rules, but with more flexibility in the filing fiduciary entities than in the non-filing fiduciary relationships. ${ }^{33}$

\section{COMPENSATION AND DISGORGEMENT}

In the event of the fiduciary's breach of duty, the principal is entitled to an election among remedies that include compensatory damages to offset any losses or to makeup any gains forgone owing to the fiduciary's breach, or to disgorgement by the fiduciary of any profit accruing to the fiduciary owing to the breach. ${ }^{34}$ The former is a standard measure of make-whole compensatory damages; the latter is a restitutionary remedy arising in equity in the form of a constructive trust that prevents unjust enrichment. ${ }^{35}$

The availability of a compensatory remedy is readily explainable on ordinary contractarian terms. The principal is entitled to the benefit of his bargain, hence to be made whole for his losses incurred or gains foregone owing to the breach. But compensatory damages deter breach only when the gains to the breaching party are less than the nonbreaching party's loss. If only

\footnotetext{
${ }^{32}$ See, e.g., Lonergan v. EPE Holdings, LLC, 5 A.3d 1008, 1016-19 (Del. Ch. 2010) (enforcing a waiver of fiduciary obligation in an LLC agreement, but applying the implied contractual covenant of good faith and fair dealing); LARRY E. RIBSTEIN, THE RISE OF THE UnCORPORATION 219-22 (2010); Paul M. Altman \& Srinivas M. Raju, Delaware Alternative Entities and the Implied Contractual Covenant of Good Faith and Fair Dealing Under Delaware Law, 60 Bus. LAw. 1469 (2005); Andrew S. Gold, On the Elimination of Fiduciary Duties: A Theory of Good Faith for Unincorporated Firms, 41 WAKE FoREST L. REV. 123 (2006); Sandra K. Miller, Role of the Court in Balancing Contractual Freedom with the Need for Mandatory Constraints on Opportunistic and Abusive Conduct in the LLC, 152 U. PA. L. REV. 1609 (2004); Myron T. Steele, Judicial Scrutiny of Fiduciary Duties in Delaware Limited Partnerships and Limited Liability Companies, 32 DEL. J. CORP. L. 1 (2007).

33 Compare Uniform Statutory Trust Entity ACt § 104 (2009), and Revised UNiform Limited LiabiLITY COMPANY ACT $\S 110$ (2006), and UNIFORM Limited PARTNERSHIP ACT $\S 110$ (2001), and REVISED Uniform PARTNERSHIP ACT $§ 103$ (1997), and Uniform Limited Liability Company ACt $§ 103$ (1996), and Mark J. Loewenstein, Fiduciary Duties and Unincorporated Business Entities: In Defense of the "Manifestly Unreasonable” Standard, 41 Tulsa L. REV. 411 (2006) (discussing mandatory rules in the uniform alternative entity acts), with UNIFORM POWER OF ATTORNEY ACT $§ 114$ (2006), and UNIFORM TRUST CODE $§ 105$ (2000), and Langbein, supra note 28 (discussing mandatory rules in the Uniform Trust Code).

${ }^{34}$ See, e.g., Uniform Trust Code $\S 1002($ a) (2000); 4 Austin WAKeman Scott, William Franklin Fratcher \& Mark L. Ascher, SCOTt AND Ascher On Trusts $§ 24.9$ (4th ed. 2007).

35 See Restatement (Third) of Agency $\S$ 8.01, cmt. d(1) (2006); Restatement (THIRD) OF RestiTUTION $\S 55$ (Tentative Draft No. 6, 2008).
} 
compensatory damages are available, and the gains to the breaching party from breach exceed the nonbreaching party's loss, then breach is efficient, and there is no need before breaching to return to the other party to negotiate over the allocation of the surplus arising from the breach. ${ }^{36}$

By contrast, the availability of a disgorgement remedy, which allows the principal to take the fiduciary's gain even in excess of making the principal whole, reflects the additional deterrent and disclosure purposes of fiduciary law. ${ }^{37}$ Because the fiduciary is not entitled to keep the gains from breach, the fiduciary is deterred from unilateral breach, and is instead given an incentive to disclose the potential gains from breach and seek the principal's consent. That is, the default rule in fiduciary law is that all gains that arise in connection with the fiduciary relationship belong to the principal unless the parties specifically agree otherwise. This default rule, which is contrary to the interests of the party with superior information, ${ }^{38}$ induces the fiduciary to make full disclosure so that the parties can complete the contract expressly as regards the principal's and the fiduciary's relative shares of the surplus arising from the conduct that would otherwise have constituted a breach.

\section{CONCLUSION}

In contrast to a normal relationship, in which each party is free to be selfserving, in a fiduciary relationship the law requires the fiduciary to be otherregarding because of the potential for abuse inherent to the agency structure of the relationship. What is meant by other-regarding is defined by default fiduciary duties of loyalty, care, and a host of implementing sub-rules. These duties are subject to refinement by agreement of the parties, so long as the fiduciary remains obligated to act in good faith and in the interests of the principal. Agency theory, and in particular its emphasis on the problem of opportunism in circumstances of asymmetric information, explains these basic contours of fiduciary doctrine.

\footnotetext{
36 See, e.g., Richard A. Posner, Economic Analysis of Law $§ 4.10$ (7th ed. 2007).

37 See supra notes 13-15 and accompanying text.

38 See Ian Ayres \& Robert Gertner, Filling Gaps in Incomplete Contracts: An Economic Theory of Default Rules, 99 YALE L.J. 87 (1989).
} 